\title{
A COMPARISON OF LIGNIN AND STABLE CARBON ISOTOPE COMPOSITIONS IN QUATERNARY MARINE SEDIMENTS*
}

\author{
JOHN I. HEDGES** and ALEXANDER VAN GEEN \\ Department of Oceanography, WB-10, University of Washington, Seattle, \\ WA 98195 (U.S.A.)
}

(Received May 19, 1981; revision accepted September 22, 1981)

\section{ABSTRACT}

Heges, J.I. and van Geen, A., 1982. A comparison of lignin and stable carbon isotope compositions in quaternary marine sediments. Mar. Chem., 11: 43-53.

Organic matter in four Quaternary sediment cores from the Gulf of Mexico and one core from the Washington State coast have been analyzed for lignin and stable carbon isotope compositions. Holocene sequences of all five cores contain organic matter with high relative abundances of ${ }^{13} \mathrm{C}\left(\delta^{13} \mathrm{C}=-19.0\right.$ to $-22.5 \%$ versus $\left.\mathrm{PDB}\right)$ and low lignin concentrations, both of which are consistent with a marine origin. Distinctly lower ${ }^{13} \mathrm{C}$ concentrations $\left(\delta^{13} \mathrm{C}=-24.0\right.$ to $\left.-25.5 \%\right)$ occur in underlying glacial-age sequences from four of the five cores, including the core from the Washington coast where such trends are previously unreported. Although the carbon isotopic compositions of these Pleistocene sediments are typical of predominantly land-derived organic matter, they contain only about 5\% of the lignin found in modern sediments of similar $\delta^{13} \mathrm{C}$ from adjacent continental shelves. The lignin-poor organic matter in the glacial-age deposits appears to be either marine-derived or terrigenous material that likely was depleted in vascular plant debris at the time of deposition.

\section{INTRODUCTION}

The abyssal plain and northwest continental slope of the Gulf of Mexico are covered with a 1-2-m thick layer of brown foraminiferal ooze of Holocene age that overlies a thicker sequence of olive gray lutite which was deposited during the Wisconsin Ice Age (Davies, 1972a; Kennett and Huddlestun, 1972). The carbon isotope compositions of the organic materials preserved in these two horizons are distinctly different. The Holocene sediments contain organic carbon that is isotopically similar to marine plankton which now inhabit the overlying temperate waters $\left(\delta^{13} \mathrm{C}=-18\right.$ to $-22 \%$ versus $\mathrm{PDB}^{* * *}$ ) (Sackett and Thompson, 1963; Sackett, 1964). By contrast, the glacial sequence contains organic matter that is depleted in ${ }^{13} \mathrm{C}$ (Sackett, 1964 ; Newman et al., 1973) with a carbon isotope composition $\left(\delta^{13} \mathrm{C}=-23\right.$ to $-27 \%$ ) similar to that commonly reported for land plants (Degens,

* Contribution No. 1240 from the Department of Oceanography, University of Washington.

** To whom correspondence should be addressed.

**** ${ }^{13} \mathrm{C}, \%=\left\{\left[{ }^{13} \mathrm{C} /{ }^{12} \mathrm{C}\right.\right.$ (sample) $] /\left[{ }^{13} \mathrm{C} /{ }^{12} \mathrm{C}\right.$ (standard) $\left.]-1\right\} \times 1000$. All $\delta^{13} \mathrm{C}$ values reported here are relative to the PDB carbon standard. 
1969). A similar isotopic trend across the Pleistocene-Holocene boundary has been reported for a sediment core from the Cariaco Trench (Eckelmann et al., 1962). Analyses of drilled sediment cores from the northern slope of the Gulf of Mexico indicate that the pattern of ${ }^{13} \mathrm{C}$-depleted organic carbon in glacial sequences continues throughout the Quaternary sequence in this region (Rogers and Koons, 1969).

A variety of explanations have been given for the different stable carbon isotope compositions of the sedimentary organic matter in glacial and interglacial deposits from the Gulf of Mexico. One explanation is that the glacialage deposits contain predominantly land-derived organic matter (Sackett, 1964; Sackett and Rankin, 1970; Newman et al., 1973). During low sea-level stands of glacial periods the Mississippi River apparently transported large sedimentary loads that were deposited on the relatively steep inclines of the northwestern continental slope and Mississippi Cone. These sediments slumped to form turbidity currents which flowed down onto the abyssal plain, greatly increasing deposition rates over most of the basin floor (Ewing et al., 1958; Davies, 1972a). It is possible that land-derived organic matter transported in these turbidity currents produced the lobes of ${ }^{13} \mathrm{C}$-depleted organic matter in Wisconsin-age sediments which extend from near the apex of the Mississippi Cone down onto the abyssal plain (Newman et al., 1973). An apparent inconsistency in this model, however, is that the calculated levels of land-derived organic matter in the turbidities (60-80\%) (Newman et al., 1973) significantly exceed concentrations found in surface sediments from the present-day Mississippi estuary and adjacent coast (Shultz and Calder, 1976).

Most other proposed explanations for these isotopic trends include the common assumption that the ${ }^{13} \mathrm{C}$-depleted organic matter in the glacialage turbidities is marine rather than terrestrially derived. Possible mechanisms proposed for the depletion of ${ }^{13} \mathrm{C}$ in the autochthonous sedimentary organic matter include: (1) increased isotope fractionation by marine plankton as a result of cooler surface waters (Rogers and Koons, 1969); (2) diagenetic alteration via preferential destruction of ${ }^{13} \mathrm{C}$-rich organic compounds (Shultz and Calder, 1976); and (3) incorporation of ${ }^{13} \mathrm{C}$-depleted inorganic carbon by phytoplankton blooming within the influence of nutrient-rich river plumes (Sackett and Thompson, 1963). Evidence that stable carbon isotope compositions of marine plankton vary widely with species (Wong and Sackett, 1978) and sometimes independently of water temperatures (Fontugne and Duplessy, 1978) suggests that changes in species composition as a result of climatic fluctuation in the Gulf of Mexico (Kennett and Huddlestun, 1972) should also be considered in this category of explanations.

In the present study oxidation products of the phenolic biopolymer, lignin, are used to characterize the composition of organic matter in Quaternary sediment cores from the Gulf of Mexico and the Washington continental slope. These cores generally exhibit distinct shifts in stable carbon isotope composition across the Pleistocene-Holocene boundary. Lignins are 
a major component of the woody tissues of vascular land plants, but are absent from marine organisms (Sarkanen and Ludwig, 1971). Lignin oxidation products have been used to trace the remains of vascular land plants in marine sediments (Leo and Barghoorn, 1970; Pocklington and MacGregor, 1973; Gardner and Menzel, 1974) and to identify the major plant tissue sources (Hedges and Mann, 1979b).

Comparisons of the lignin and stable carbon isotope compositions of recent marine sediments from the Gulf of Mexico and Washington State continental shelf and slope indicate for these regions that lignin is a major component of the terrigenous fraction and that lignin oxidation products are reliable indicators of the concentrations of land-derived organic matter in general (Hedges and Parker, 1976; Hedges and Mann, 1979b). Recent evidence for the chemical stability of lignins in marine and lacustrine sediments (Hedges and Mann, 1979b; Hedges et al., submitted) suggest that lignin oxidation products should also be useful for addressing the previously discussed question of the forms and origin of ${ }^{13} \mathrm{C}$-depleted organic matter in glacial-age sediments from the Gulf of Mexico and Washington regions.

\section{EXPERIMENTAL}

\section{Samples}

Four sediment cores are from a set of 48 piston cores collected from the Gulf of Mexico in 1969 and carry here the original designation numbers from those cruises. The mineralogy and micropalaeontology of these cores have been described by Davies (1972a) and Kennett and Huddlestun (1972), respectively. Other sedimentologic analyses of selected cores have been published by Davies (1972b). Sediment samples analyzed in the present study are from the set described by Newman et al. (1973). When individual samples did not contain sufficient sediment for lignin analysis, sediments of similar carbon isotope composition from consecutive sampling depths were combined. An additional core from the Washington continental slope was collected at a water depth of $1590 \mathrm{~m}$, approximately $90 \mathrm{~km}$ off the central Washington coast $\left(47^{\circ} 7.0^{\prime} \mathrm{N}, 125^{\circ} 20.1^{\prime} \mathrm{W}\right)$. The 26 -cm long box core was sliced into $2-$ to $3-\mathrm{cm}$ thick horizontal sections which were immediately homogenized and frozen.

\section{Analyses}

Stable carbon isotope compositions were measured as described by Newman et al. (1973). Weight percentages of organic carbon in all Gulf of Mexico sediments were determined by manometric measurement of $\mathrm{CO}_{2}$ produced after high temperature combustion in a radio frequency furnace (Calder and Parker, 1973). Weight percentages of organic carbon and $\mathrm{C} / \mathrm{N}$ ratios were determined for all Washington slope sediments with a Carlo Erba 
Model 1106 elemental analyzer with average reproducibilities (calculated as percent mean sample deviations $\left.\left[100 \Sigma\left|X_{i}-\bar{X}\right|\right] / n \bar{X}\right)$ of $\pm 1 \%$ and $\pm 2 \%$, respectively, (based on 11 duplicates).

Lignin oxidation products of all Gulf of Mexico sediments were determined as described by Hedges and Parker (1976). Identities of the reported compounds were confirmed by analysis of the phenolic mixture from sample 87-4 with a C.E.C. Model 21-491 GC-mass spectrometer.

Lignin oxidation products of samples from the Washington slope sediment core were determined by a modified version of the method described by Hedges and Parker (1976). The major difference was that the oxidation product mix tures were analyzed (also as trimethylsilyl derivatives) on high resolution fused silica gas chromatographic columns coated with methylsilicone (OV-101) liquid phase. The standard mixture included all the components which are identified in the gas chromatographic trace illustrated in Fig. 1. Analytical results for all samples are reported in the form of 'lignin parameters' as described by Hedges and Mann $(1979 a, b)$. Duplicate analyses of

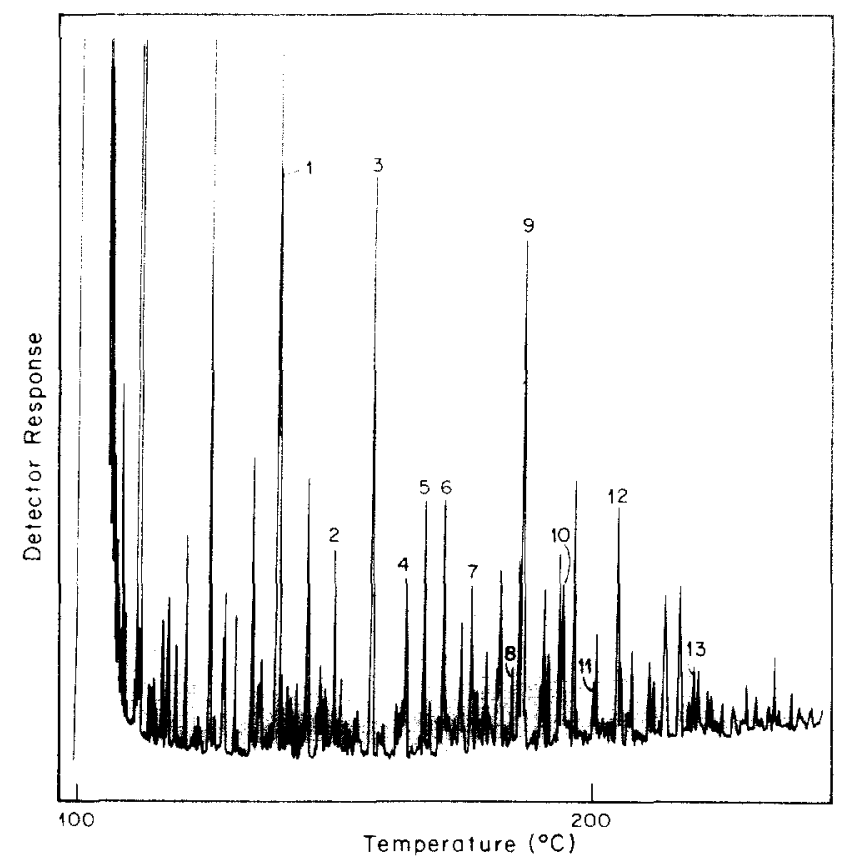

Fig. 1. Gas chromatogram of the oxidation product mixture obtained from Washington slope sediment sample TT120-18-2 (Table II). All compounds were converted to trimethylsilyl derivatives before analysis on a $25 \mathrm{~m} \times 0.23 \mathrm{~mm}$ i.d. fused silica column coated with OV-101 methylsilicone liquid phase. Oven temperature was held at $100^{\circ} \mathrm{C}$ for 2 min after injection and then raised at $4^{\circ} \mathrm{min}^{-1}$ to $280^{\circ} \mathrm{C}$. The carrier gas was helium at a flow rate of approximately $1 \mathrm{~cm}^{3} \mathrm{~min}^{-1}$. Peak identities: $1, p$-hydroxybenzaldehyde; $2, p$-hydroxyacetophenone; 3 , vanillin; $4, m$-hydroxybenzoic acid; 5 , acetovanillone; 6 , $p$-hydroxybenzoic acid; 7 , syringaldehyde; 8 , acetosyringone; 9 , vanillic acid; $10,3,5$ dihydroxybenzoic acid; 11 , syringic acid; $12, p$-coumaric acid; 13 , ferulic acid. 


\section{TABLE I}

Lignin parameter reproducibilities for two pairs of sediment samples analyzed with high resolution fused silica GC columns*

\begin{tabular}{llllllll}
\hline Sample & $\mathrm{V}$ & $\mathrm{S}$ & $\mathrm{C}$ & $\mathrm{S} / \mathrm{V}$ & $\mathrm{C} / \mathrm{V}$ & $\lambda$ & $\Lambda$ \\
\hline TT120-18-4 & 0.14 & 0.053 & 0.033 & 0.38 & 0.24 & 0.20 & 0.24 \\
TT120-18-4 & 0.17 & 0.055 & 0.046 & 0.32 & 0.27 & 0.24 & 0.28 \\
$\begin{array}{l}\text { Average } \\
\text { \% deviation }\end{array}$ & 0.16 & 0.054 & 0.040 & 0.35 & 0.26 & 0.22 & 0.26 \\
& 10 & 1 & 16 & 9 & 6 & 9 & 8 \\
TT120-18-8 & 0.29 & 0.101 & 0.065 & 0.35 & 0.22 & 0.51 & 0.61 \\
TT120-18-8 & 0.24 & 0.077 & 0.061 & 0.32 & 0.25 & 0.42 & 0.50 \\
$\begin{array}{l}\text { Average } \\
\text { \% deviation }\end{array}$ & 0.26 & 0.089 & 0.63 & 0.34 & 0.24 & 0.46 & 0.56 \\
Average \% deviation & 10 & 13 & 3 & 4 & 6 & 10 & 10 \\
& 10 & 7 & 10 & 7 & 6 & 10 & 9 \\
\hline
\end{tabular}

* All lignin parameters are defined in the text.

** Calculated as the percent sample mean deviation.

lignin parameters for two pairs of sediment samples from the Washington slope core (Table I) yielded precisions similar to those previously reported for this general method (Hedges and Parker, 1976; Hedges and Mann, $1979 b)$.

\section{RESULTS AND DISCUSSION}

\section{Carbon isotope and organic elemental analyses}

The $\delta^{13} \mathrm{C}$ values and weight percentages of organic carbon for individual samples from the five sediment cores are given in Table II. Isotopic trends for the four Gulf of Mexico cores are essentially as reported by Newman et al. (1973) for the same sediment sequences. Cores 87 and 97 from the western abyssal plain and core 102 from the northwestern continental slope exhibit sharp isotopic breaks from an average $\delta^{13} \mathrm{C}$ value of $-20.3 \pm 1.0 \%$ (one standard deviation from the mean) $(n=7)$ for the Holocene foraminiferal ooze to an average value of $-24.8 \pm 0.6 \%(n=7)$ for the underlying Wisconsin-age lutite. Core 136 from the Tabasco-Campeche Knolls area of the southwestern continental slope exhibits no discernible difference in $\delta^{13} \mathrm{C}$ across the Pleistocene-Holocene boundary at about $1.5-\mathrm{m}$ depth in the core which nevertheless can be identified by a change in planktonic foraminiferal composition (Kennett and Huddlestun, 1972). Uniformly ${ }^{13} \mathrm{C}$-rich organic carbon is typical of sediment cores from this region (Newman et al., 1973).

Core TT120-18 from the Washington continental slope consists of an olive gray clay $(0-14 \mathrm{~cm})$ grading into gray clay in the lower section $(20-24 \mathrm{~cm})$. Occurrences of Holocene olive gray clay overlying Late Pleistocene gray 
clay are common in coastal regions of the northeast Pacific (Barnard and McManus, 1973; Heusser and Florer, 1973; Nelson, 1976; Duncan et al., 1970). However, the relatively thin Holocene sequence of core TT120-18 and the absence of the Mazama ash horizon (Nelson et al., 1968; Heusser and Florer, 1973) within it both suggest a discontinuous PleistoceneHolocene contact.

The Washington slope core also exhibits an isotopic break from an average $\delta^{13} \mathrm{C}$ of $-22.0 \pm 0.3 \%(n=5)$ in the upper $17 \mathrm{~cm}$ of the core to an average $\delta^{13} \mathrm{C}$ of $-25.0 \pm 0.7 \%(n=2)$ for gray clay samples from depths greater than $20 \mathrm{~cm}$. These average $\delta^{13} \mathrm{C}$ values for the Holocene and Pleistocene sequences of core TT $120-18$ are within $\pm 0.5 \%$, respectively, of previously published estimates for marine- and terrestrially-derived organic carbon in modern sediments from the Washington coastal region (Hedges and Mann, 1979b). As opposed to the Gulf of Mexico cores which have relatively uniform weight percentages of organic carbon throughout, the Washington slope core exhibits a large decrease in organic carbon from values near $3 \%$ at the top to values of approximately $0.4 \%$ within the gray clay. A portion of the strong organic carbon gradient over the middle portion of the core may result from mixing of the gray and olive gray clays.

Atomic $\mathrm{C} / \mathrm{N}$ ratios are relatively constant over the upper $17 \mathrm{~cm}$ of the Washington slope core with an average value of $10.8 \pm 0.6$ (Table II). The mean atomic $\mathrm{C} / \mathrm{N}$ of organic material in the bottom $7 \mathrm{~cm}$ of sediment $(15.9 \pm 3.2)$ is significantly higher. (All tests for 'significant' differences cited herein have been made using the $t$ statistic for 2 means at the $95 \%$ confidence level (Brownlee, 1965).)

\section{Lignin oxidation products}

A representative gas chromatogram of the cupric oxide oxidation products yielded by a sediment sample from the Washington continental slope is shown in Fig. 1. The mixture of ether-extractable acidic reaction products includes eight phenols which are obtained only from lignin and, therefore, are useful as indicators of vascular plant remains (Hedges and Parker, 1976; Hedges and Mann, 1979a, b). These eight phenols constitute an unmistakable chemical signature (Fig. 1) and provide additional information about the types of vascular plant tissues present in the sedimentary organic mixture (Hedges and Mann, 1979a, b).

Lignin parameters for individual sediment samples from the five sediment cores are given in Table II. All the reported parameters are generated from the basic parameters $\mathrm{V}, \mathrm{S}$ and $\mathrm{C}$ which are, respectively, the total yields (in milligrams) of vanillyl, syringyl and cinnamyl phenols obtained from the oxidation of $100 \mathrm{mg}$ of organic carbon in the sediment sample (Hedges and Mann, 1979a). The parameter $\lambda$, which corresponds to $(S+V)$, is used here as an indicator of the relative concentration of lignin in individual sediment samples. ( $\lambda$ is used in preference to $\Lambda(S+V+C)$ in the present study be- 
cause $\mathrm{C}$ values are not available for the Gulf of Mexico samples.) The parameters $\mathrm{S} / \mathrm{V}$ and $\mathrm{C} / \mathrm{V}$ (the latter only for Washington sediments) reflect the relative levels of woody and non-woody tissues from gymnosperm and angiosperm plants which occur in the deposits (Hedges and Mann, 1979a).

Measurable lignin oxidation product yields $(\lambda \geqslant 0.05)$ were obtained for half of the Gulf of Mexico sediment samples and for all of the Washington continental slope samples (Table II). As whole, $\lambda$ values for these sediments are low in comparison to values for vascular plant tissues, 2-25 (Hedges and Mann, 1979a), and continental shelf sediments, 0.1-9 (Hedges and Parker, 1976; Hedges and Mann, 1979b). Average $\lambda$ values for Holocene $(0.06 \pm 0.15$, $n=9)$ and Pleistocene $(0.10 \pm 0.10, n=9)$ sediments from the Gulf of Mexico are not significantly different (values $<0.05$ averaged as zero). Sedimentary organic matter from the Washington slope core produces greater yields of lignin-derived phenols with a significant difference between mean $\lambda$ values for Holocene $(0.24 \pm 0.03, n=6)$ and Pleistocene $(0.39 \pm 0.08$, $n=3$ ) sediments. (Sample 7 (for which no $\delta^{13} \mathrm{C}$ value was determined) has been included in the Pleistocene group based on its high $\mathrm{C} / \mathrm{N}$ and $\lambda$ values.) As would be expected from the previous discussion, correlation between $\lambda$ and $\delta^{13} \mathrm{C}$ is observed only for the Washington slope sediments $\left(r^{2}=0.71\right.$, $n=9$ ).

The extremely low $\lambda$ values of the Holocene sediments from the four Gulf of Mexico cores are consistent with previous studies which indicate efficient sedimentation of land-derived organic matter in estuaries and on inner continental shelves of the western Gulf (Hedges and Parker, 1976; Shultz and Calder, 1976; Gearing et al., 1977). Similarly, low $\lambda$ values for the Holocene sequence in core TT120-18 correspond well with previous determinations for a nearby core of Holocene sediment (Hedges and Mann, $1979 \mathrm{~b}$; core 7). A more interesting result of this study is the extremely low lignin phenol yield from the ${ }^{13} \mathrm{C}$-depleted Pleistocene sediments of both the western Gulf of Mexico and the mid-Washington slope. On the average, these sediments produce only about $5 \%$ of the lignin oxidation product that would be expected based upon $\delta^{13} \mathrm{C}-\lambda$ correlations for modern sediments from the adjacent continental shelves (Hedges and Parker, 1976, fig. 5; Hedges and Mann, $1979 \mathrm{~b}$, fig. 4).

Only four of the eighteen Gulf of Mexico sediment samples produce sufficient lignin oxidation product $(\lambda \geqslant 0.10)$ for reliable determinations of $\mathrm{S} / \mathrm{V}$ by the analytical method used for these samples (Hedges and Parker, 1976). As a result, trends in $S / V$ with age and sediment type are difficult to evaluate. The mean $\mathrm{S} / \mathrm{V}$ of the four sediments, three of which are of Pleistocene age, is $1.1 \pm 0.5$. Values of $\mathrm{S} / \mathrm{V}$ in this range are typical of modern sediments from the western continental shelf of the Gulf of Mexico (Hedges and Parker, 1976) and reflect an angiosperm-rich lignin composition.

The lignin compositions of the Holocene and Pleistocene segments of the Washington slope core are essentially identical although significant differences in both isotopic and elemental organic compositions exist (Table II). 


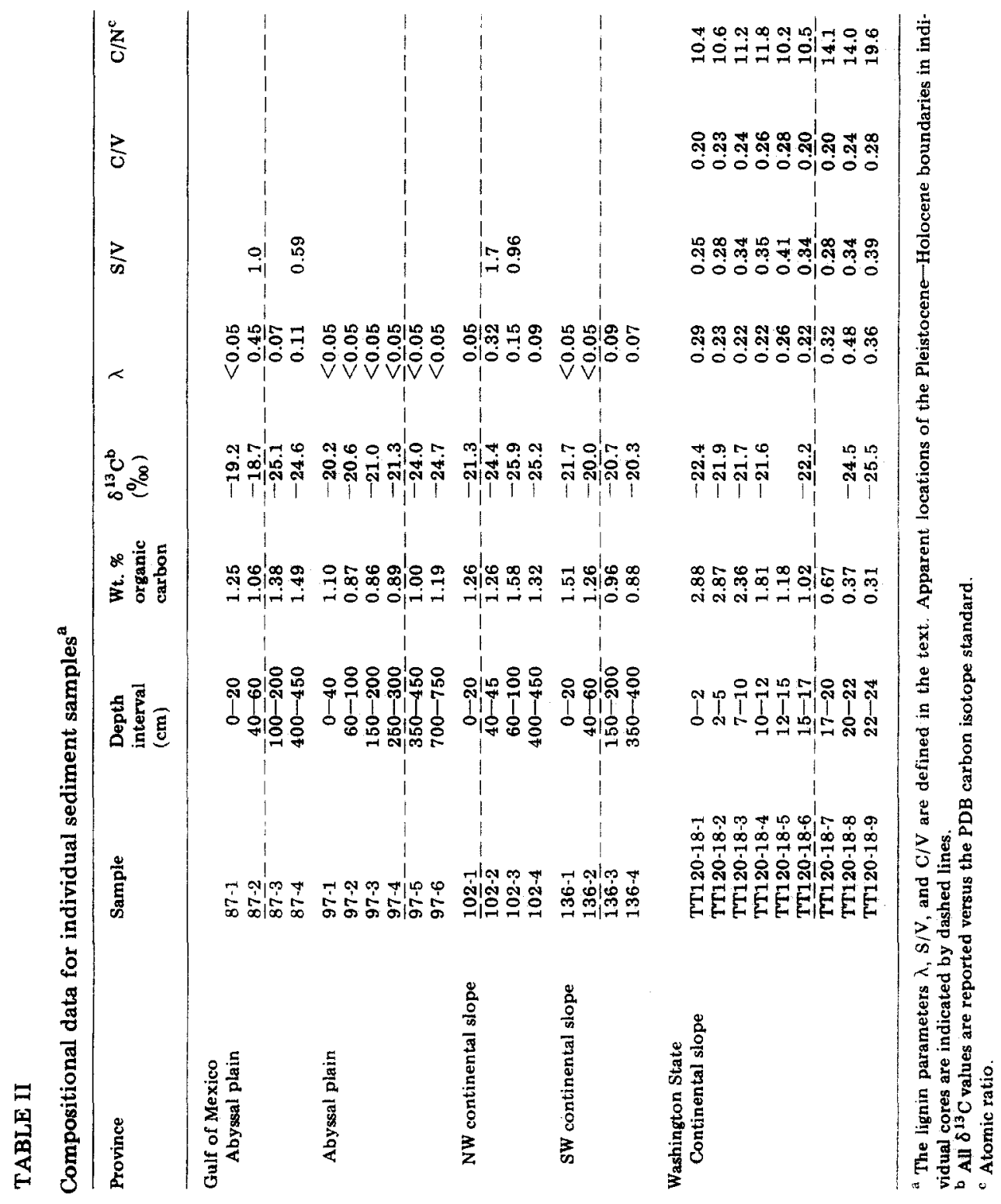


The average $\mathrm{S} / \mathrm{V}$ and $\mathrm{C} / \mathrm{V}$ values for the entire core $(0.33 \pm 0.05$ and 0.24 \pm 0.03 , respectively) are similar to those previously reported for modern sediments from the Washington slope (Hedges and Mann, 1979b). The low S/V values of these sediments are typical of modern Washington coastal marine deposits and reflect a predominance of coniferous trees on adjacent land areas (Hedges and Mann, 1979b).

A finding of high $\lambda$ values in the range of $2-6$ for the ${ }^{13} \mathrm{C}$-depleted Pleistocene clays would conclusively demonstrate high concentrations of vascular plant remains and, therefore, a predominantly terrigenous origin for the associated organic matter. The actual result of order-of-magnitude lower $\lambda$ values is more ambiguous with at least three plausible explanations.

The first explanation is that the ${ }^{13} \mathrm{C}$-depleted organic matter is predominantly of terrigenous origin with an initially high lignin concentration that has been subsequently reduced by extensive in situ degradation. Although this explanation is supported by the significantly higher $\mathrm{C} / \mathrm{N}$ of the gray clay in core TT120-18, it is inconsistent with at least three other lines of evidence. First, analyses of cores of modern sediment from a variety of depositional environments on the Washington State continental shelf and slope give no evidence for appreciable in situ lignin degradation over time periods of up to $400 \mathrm{y}$ (Hedges and Mann, 1979b). Such time intervals should be generally sufficient to allow passage of organic materials through biologically active surface sediments after which rapid degradation at greater depth seems unlikely. Second, analyses of an apparently complete Holocene sequence in an 11-m long sediment core from Lake Washington near Seattle indicates excellent lignin preservation over the entire approximate $13000-y$ record (Hedges et al., submitted). Finally, the regionally typical lignin compositions of all sediments in this study and absence of consistent decreases in lignin concentration within individual Holocene and Pleistocene core sequences (Table II) also suggest minimal in situ degradation.

The second explanation is that the ${ }^{13} \mathrm{C}$-depleted organic matter, although predominantly of terrestrial origin, was deposited during glacial times with a much lower initial lignin content than land-derived organic matter now being introduced to the same regions. This model would necessitate either a drastic reduction in the ratio of vascular plant debris to more lignin-poor terrigenous organic substances (such as non-vascular plant remains, soil humus or eroded coals and kerogens) and/or a continuously efficient mechanism for the selective removal of lignin-bearing organic materials during transport to the ultimate deposition site. A lower concentration of chemically intact lignin in a predominantly terrigenous input is consistent with the measured lignin, stable carbon isotope and elemental compositions (Table II) and with the recent finding of comparably low $\lambda$ values for early post-glacial gray clay from Lake Washington where terrigenous organic matter could be expected to accumulate with minimal degradation and dilution (Hedges et al., submitted).

Finally, the organic matter in the glacial-age sediments may be predom- 
inantly marine derived, under which conditions low concentrations of vascular plant remains would be expected. The potential for autochthonous organic input is indicated by the visible remains of foraminifera and other strictly marine micro-organisms in Pleistocene deposits from both the Gulf of Mexico (Kennett and Huddlestun, 1972) and Washington slope (Barnard and McManus, 1973). However, the lignin analytical technique used here does not allow at this time specific identification of marine-derived organic matter at the molecular level. Thus, the two remaining most likely hypotheses of a marine origin or lignin-poor terrigenous source for the ${ }^{13} \mathrm{C}$-depleted organic matter in these glacial-age deposits remain to be tested by other means.

\section{CONCLUSIONS}

(1) The occurrence of ${ }^{13} \mathrm{C}$-depleted organic matter in Pleistocene marine sediments is widespread, including at least one coastal region in the northeast Pacific.

(2) Organic matter in these sediments contains low concentrations of chemically intact vascular plant remains as indicated by small yields of lignin-derived phenols.

(3) Relatively uniform lignin concentrations and compositions within individual sediment cores suggest minimal in situ lignin degradation.

(4) The most likely explanations for these observations are either that the ${ }^{13} \mathrm{C}$-depleted organic matter in the glacial-age deposits is marine derived or, if of terrestrial origin, was markedly poor in vascular plant remains at the time of deposition.

\section{ACKNOWLEDGEMENT}

Acknowledgement is made to the donors of the Petroleum Research Fund, administered by the ACS, for partial support of this research. This research was also funded in part by DOE contract AT(45-1)-2225-T40 (now under the U.S. Environmental Protection Agency), We thank Drs. Patrick Parker, Thomas C. Hoering, Roy Carpenter, their students and associates for numerous contributions. John Ertel, in particular, has contributed to this work.

\section{REFERENCES}

Barnard, W.D. and McManus, D.A., 1973. Planktonic foraminiferan-radiolarian stratigraphy and the Pleistocene-Holocene boundary in the northeast Pacific. Geol. Soc. Am. Bull., 84: 2097-2100.

Brownlee, K.A., 1965. Statistical Theory and Methodology in Science and Engineering. Wiley, New York, NY.

Calder, J.A. and Parker, P.L., 1973. Geochemical implication of induced changes of $\mathrm{C}^{13}$ fractionation by blue green algae. Geochim. Cosmochim. Acta, 37: 133-140.

Davies, D.K., 1972a. Deep sea sediments and their sedimentation, Gulf of Mexico. Am. Assoc. Petrol. Geol. Bull., 56: 2212-2239. 
Davies, D.K., 1972b. Mineralogy, petrography and derivation of sands and silts of the continental slope, rise, and abyssal plain of the Gulf of Mexico. J. Sediment. Petrol., 42: $59-65$.

Degens, E.T., 1969. Biogeochemistry of stable carbon isotopes. In: G. Eglinton and M.T.J. Murphy (Editors), Organic Geochemistry. Springer-Verlag, New York, NY, pp. 304-328.

Duncan, J.R., Kulm, L.D. and Griggs, G.B., 1979. Clay mineral composition of Late Pleistocene and Holocene sediments of Cascadia Basin, northeastern Pacific Ocean. J. Geol., 78: 213-221.

Eckelmann, W.R., Broecker, W.S., Whitlock, D.W. and Allsup, J.R., 1962. Implications of carbon isotopic composition of total organic carbon of some Recent sediments and ancient oils. Am. Assoc. Petrol. Geol., 46: 699-704.

Ewing, M., Ericson, D.B. and Heezen, B.C., 1958. Sediments and topography of the Gulf of Mexico. In: L.G. Weeks (Editor), Habitat of Oil. American Association of Petroleum Geologists, Tulsa, OK, pp. 995-1054.

Fontugne, M. and Duplessy, J.C., 1978. Carbon isotope ratio of marine plankton related to surface water masses. Earth Planet. Sci. Lett., 41: 365-371.

Gardner, W.S. and Menzel, D.W., 1974. Phenolic aldehydes as indicators of terrestrially derived organic matter in the sea. Geochim. Cosmochim. Acta, 38: 813-822.

Gearing, P., Plucker, F.E. and Parker, P.L., 1977. Organic carbon stable isotope ratios of continental margin sediments. Mar. Chem., 5: 251-266.

Hedges, J.I. and Mann, D.C., 1979a. The characterization of plant tissues by their lignin oxidation products. Geochim. Cosmochim. Acta, 43: 1803-1807.

Hedges, J.I. and Mann, D.C., 1979b. The lignin geochemistry of marine sediments from the southern Washington coast. Geochim. Cosmochim. Acta, 43: 1809-1818.

Hedges, J.I. and Parker, P.L., 1976. Land-derived organic matter in surface sediments from the Gulf of Mexico. Geochim. Cosmochim. Acta, 40: 1019-1029.

Hedges, J.I., Ertel, J.R. and Leopold, E.B. Lignin geochemistry of a Holocene sediment core from Lake Washington. Submitted to Geochim. Cosmochim. Acta.

Heusser, C.J. and Florer, L.E., 1973. Correlation of marine and continental Quaternary pollen records from the northeast Pacific and western Washington. Quat. Res., 3: $661-670$.

Kennett, J.P. and Huddlestun, P., 1972. Late Pleistocene paleoclimatology, foraminiferal biostratigraphy and tephrochronology, western Gulf of Mexico. Quat. Res., 2: 38-69.

Leo, R.F. and Barghoorn, E.S., 1970. Phenolic aldehydes: generation from fossil woods and carbonaceous sediments by oxidative degradation. Science, 168: 582-584.

Newman, J.W., Parker, P.L. and Behrens, E.W., 1973. Organic carbon isotope ratios in Quaternary cores from the Gulf of Mexico. Geochim. Cosmochim. Acta, 37: 225238.

Nelson, H., 1976. Late Pleistocene and Holocene depositional trends, processes and history of Astoria deep-sea fan, northeast Pacific. Mar. Geol., 20: 129-273.

Nelson, C.H., Kulm, L.D., Carlson, P.R. and Duncan, J.R., 1968. Mazama ash in the northeastern Pacific. Science, 161: 47-49.

Pocklington, R. and MacGregor, C.D., 1973. The determination of lignin in marine sediments and particulate form in seawater. J. Environ. Anal. Chem., 3: 81-93.

Rogers, M.A. and Koons, C.B., 1969. Organic carbon $\delta \mathrm{C}^{13}$ values from Quaternary marine sequences in the Gulf of Mexico: a reflection of paleotemperature changes. Trans. Gulf Coast Assoc. Geol. Soc., XIX: 529-534.

Sackett, W.M., 1964. The depositional history and isotopic organic carbon composition of marine sediments. Mar. Geol., 2: 173-185.

Sackett, W.M. and Rankin, J.G., 1970. Paleotemperatures for the Gulf of Mexico. J. Geophys. Res., 24: 4557-4560. 
Sackett, W.M. and Thompson, R.R., 1963. Isotopic organic carbon composition of recent continental derived clastic sediments of eastern Gulf coast, Gulf of Mexico. Bull. Am. Assoc. Petrol. Geol., 47: 525-531.

Sarkanen, K.V. and Ludwig, C.H., 1971. Lignins. Wiley-Interscience, New York, NY.

Shultz, D.J. and Calder, J.A., 1976. Organic carbon ${ }^{13} \mathrm{C} /{ }^{12} \mathrm{C}$ variations in estuarine sediments. Geochim. Cosmochim. Acta, 40: 381-385.

Wong, W.W. and Sackett, W.M., 1978. Fractionation of stable carbon isotopes by marine phytoplankton. Geochim. Cosmochim. Acta, 42: 1809-1815. 